УДК 621.777 .04

\author{
Алісва Л. І. \\ Алісв I. С. \\ Грудкіна Н. С. \\ Малій X. В.
}

\title{
МОДЕЛЮВАННЯ ПРОЦЕСУ КОМБІНОВАНОГО РАДІАЛЬНО-ЗВОРОТНОГО ВИДАВЛЮВАННЯ ДЕТАЛЕЙ 3 ФЛАНЦЕМ
}

Стрижневі деталі з фланцем і осьовим відростком є досить поширеними в приладота машинобудуванні. Поширеною і освоєною технологією отримання деталей такого типу $\epsilon$ багатоперехідна висадка, а також радіальне або пряме видавлювання, доповнене, як правило, операцією висадки (осадки) фланця [1-3].

Процеси холодного деформування характеризуються високими питомими і повними зусиллями на інструмент, що знижують його стійкість і стабільність процесу $[1,3]$. Способи деформування, що спрямовані для зниження цих обмежень, передбачають створення більш сприятливих для силового режиму різнойменний схем напружено-деформованого стану, зменшення площі контакту активного деформуючого інструменту із заготовкою, зниження навантажень на інструмент за рахунок забезпечення більшого ступеня свободи витікання металу або розвиненої радіальної течії (роздачі металу) [3]. Комбінування схем поздовжнього і радіального видавлювання може бути методом створення більш складних способів деформування, які можуть дозволить виготовити за одну операцію порожнисті і суцільні деталі з фланцями або відростками, або більш складних просторових конфігурацій [4]. При цьому в залежності від типорозміру виробів і мети суміщення простих схем деформування можливе застосування того чи іншого поєднання простих схем видавлювання.

Для складнопрофільованих багатоступеневих деталей з фланцем більш продуктивною представляється технологія комбінованого видавлювання, що поєднує способи поперечного радіального і поздовжнього (зворотного або прямого) видавлювання [4-6]. На рис. 1 представлені способи штампування стрижневих деталей з фланцем. Схеми 1 і 2 об'єднують способи деформування з переважним прямим видавлюванням осьового відростка, а схеми 3 і 4 об'єднує способи з радіально-зворотним видавлюванням деталі. Способи радіально-прямого видавлювання доцільно застосовувати при роз'єднаному розташуванні корпусу і відростка, а способи радіально-зворотного видавлювання - при односторонньому розташуванні корпусу і відростка відносно фланця.

У попередніх дослідженнях відзначена особливість положення фланця і його роль в комбінованому процесі, де в одному осередку деформації поєднуються радіальне видавлювання фланця і пряме видавлювання відростка $[3,4]$. Фланець, який вже сформований, може грати роль застійної зони, щодо якої метал продовжує інтенсивно переміщатися в прямому напрямку. Це призводить до відділення фланця по лініях максимального зсуву через вичерпання ресурсу пластичності металу.

Цього недоліку позбавлений менш вивчений спосіб радіально-зворотного видавлювання деталей, в якому, з одного торця заготовки видавлюють фланець, а 3 протилежного торця - осьовий відросток або порожнистий стрижень. Попередні експериментальні і теоретичні дослідження даного способу показують перспективні можливості процесу для отримання якісних деталей з легкодеформуючих матеріалів $[2,7,8]$. Обмеження може бути пов'язано 3 необхідністю використання полого пуансона, який повинен бути досить надійним при обробці металу в холодному стані.

Метою даного дослідження $\epsilon$ оцінка технологічних режимів способу радіальнозворотного видавлювання і можливостей формоутворення стрижневих деталей з осьовим відростком і фланцем в суміщеному процесі. 


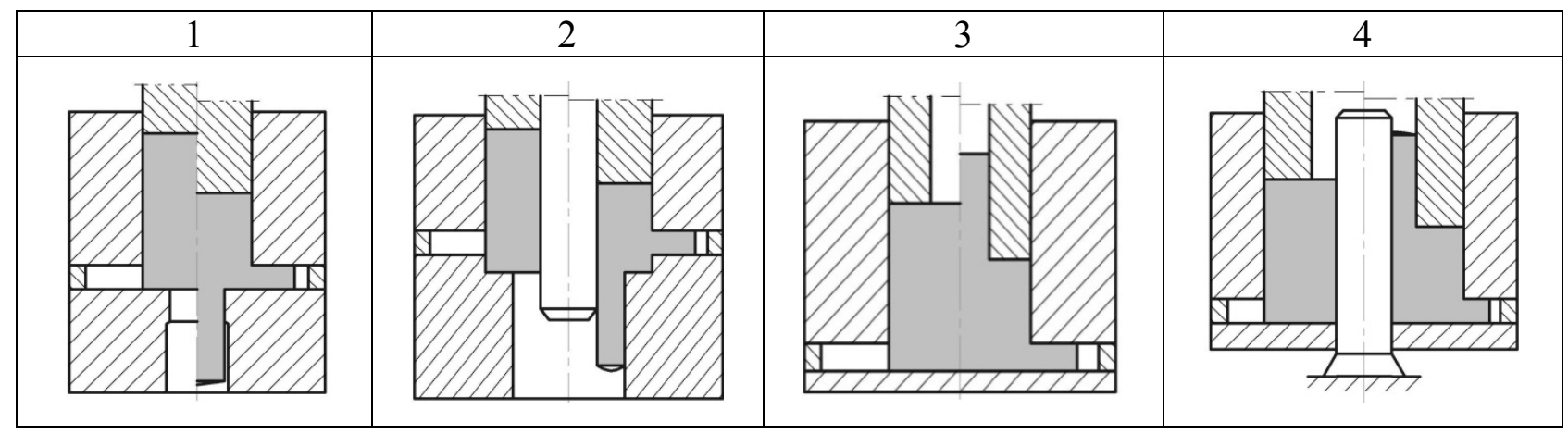

Рис. 1. Схеми радіально-поздовжнього видавлювання

Типові представники (рис. 2, а) стрижневих деталей з фланцем містять три основні частини: фланець 3 найбільшим діаметром $D_{1}$ та товщиною $h$, корпус деталі з середнім діаметром $D_{0}\left(2 R_{0}\right)$ та висотою $H$ та осьовий стрижень 3 діаметром $d(2 R)$ та довжиною $l$. У найбільш простому випадку виродження корпусу і його злиття з фланцем ми отримаємо деталь типу клапана або гвинта.

Для теоретичного аналізу силового режиму обраний енергетичний метод верхньої оцінки, заснований на балансу потужностей на кінематично можливих швидкостях переміщень [9-11]. Кінематичне можливі поля швидкостей (КМПШ) задаються на підставі попередньо проведених експериментальних досліджень і аналізу особливостей течії металу.

Особливістю схеми радіально-зворотного видавлювання $є$ те, що коли стрижень і фланець розташовані по різні сторони відносно корпусу деталі, осередок інтенсивного деформування є роз'єднаний, сформований з двох автономних осередків зворотного та радіального видавлювання металу (рис. 2, б). Роз'єднаний осередок деформування утворюється при видавлюванні відносно високих заготовок з співвідношенням висоти заготовки до ііі діаметру $H_{0} / D>1,5$.

Для осесиметричних кінематичних елементів 3 прямокутним поперечним перерізом найбільш проста схема побудови КМПШ заснована на припущенні про паралельну течію металу. Якщо складові швидкості уздовж кожного координатного напрямку не залежать від координат за іншими напрямками, тобто $v_{z}=v_{z}(z)$, то компоненти швидкості в загальному вигляді можна визначити за формулами [11]:

$$
v_{z}=C_{1} z+C_{2} ; v_{r}=-0,5 C_{1} r+\frac{C_{3}}{r} ; v_{\theta}=0
$$

де $C_{1}, C_{2}$ и $C_{3}$ - довільні постійні.

Постійні визначають виходячи з кінематичних граничних умов в швидкостях і умов безперервності нормальної складової швидкості на поверхні розриву швидкості.

Підстановка встановлених заздалегідь постійних інтегрування $C_{1}, C_{2}$ i $C_{3}$ з урахуванням кінематичних граничних умов (КГУ) дозволило отримати КМПШ для осесиметричних координатних модулів (табл. 1). Дані КМПШ не викликають складнощів в розрахунках і мають властивість вбудовуваності в більш складні схеми, будучи їх елементами.

Порядок розрахунку приведених тисків представлено в методиці застосування енергетичного методу верхньої оцінки (ЕМВО) [9-11],

Формула для обчислення приведеного тиску $\bar{p}_{1}$, що витрачено окремо для зворотного видавлювання відростку радіусом $R$, може бути отримана енергетичним методом.

$$
\pi\left(R_{0}^{2}-R^{2}\right) V_{0} \bar{p}_{1} \sigma_{s}=N_{\partial 2}+N_{\partial 3}+N_{c 2-3}+2 N_{c 3-4}+N_{c 7-2}+N_{t 1-4}+N_{t 0-2}+N_{t 1-2} .
$$


Обидві частини рівняння балансу потужностей ділимо на множник $\pi\left(R_{0}^{2}-R^{2}\right) \cdot V_{0}$, потім на $\sigma_{S}$ і отримаємо приведений тиск $\bar{p}_{1}$ на торці пуансона, а якщо, використовуючи інверсію, обчислимо $q$ прямого (знизу доверху) видавлювання стрижня з виразу:

$$
\bar{q}=\bar{p}_{1} \cdot \frac{R_{0}^{2}-R^{2}}{R_{0}^{2}} .
$$

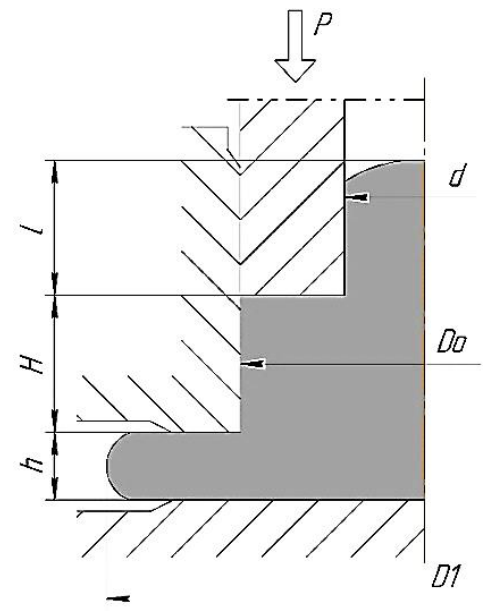

a

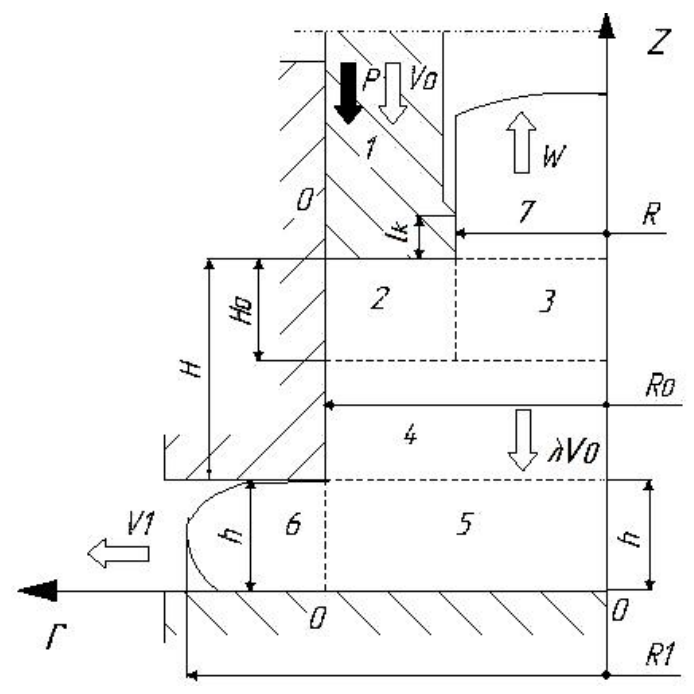

6

Рис. 2. Технологічна (а) i розрахункова (б) схеми процесу радіально-зворотного видавлювання стрижневих деталей

Приведений тиск $\bar{q}$ можна також отримати і з рівняння балансу (2), розділивши обидві частини на множник $\pi R_{0}^{2} \cdot V_{0} \cdot \sigma_{s} \cdot \bar{q}=\bar{p}_{1} \cdot\left(1-m^{2}\right)$, де $m=R / R_{0}$.

Згідно з методикою модульного підходу [12] для модулів з паралельною течією металу можна використати отримані рівняння для приведених тисків деформування, зрізу та тертя для деяких кінематичних модулів (табл. 1). Перевірка властивості інверсії напрямку векторів швидкості течії показала, що ці модулі мають властивість інверсії. Це доведено висновком формул для приведеного тиску.

Для зони 2 приймаємо залежності модулю А2 (з течією до центру), а для зони 3 - модулю С6 (див. табл. 1). Оскільки на границі 2-3 вектори швидкості $v_{z}$ спрямовані у протилежні сторони приведені тиски зрізу на цій поверхні складаються: $\Delta \bar{p}_{c 2-3}=\Delta \bar{p}_{3}+\Delta \bar{p}_{4}$. На границях зон 3 і 4, 3 і 7 витрати на зріз однакові (коефіцієнт тертя при цьому дорівнює $\mu_{s}=0,5$ ).

В результаті підбору складових приведених тисків отримаємо:

$$
\begin{gathered}
\bar{q}=\frac{1}{\sqrt{3} R_{0}^{2}} M_{1}+\frac{R_{0}^{2}-R^{2}}{R_{0}^{2}}+\frac{B_{1}}{\sqrt{3} R_{0}^{2}}++\frac{R_{0}^{2}-R^{2}}{3 \sqrt{3} H_{0}} \cdot \frac{R}{R_{0}^{2}}+\frac{H_{0} R_{0}^{2}}{\sqrt{3} R R_{0}^{2}}+ \\
+\frac{2}{\sqrt{3}} \frac{\mu_{S}}{R_{0}^{2}}\left[H_{0} R_{0}+2 R l_{k}\left(\frac{R_{0}^{2}-R^{2}}{R^{2}}+1\right)+B_{1}\right], \\
\text { де } M_{1}=\left\{2 R_{0}^{2}-\sqrt{3 R^{4}+R_{0}^{4}}+R_{0}^{2} \cdot \ln \left[\frac{\sqrt{3 R^{4}+R_{0}^{4}}+R_{0}^{2}}{3 R^{2}}\right]\right\} ; \\
B_{1}=\frac{\left(R_{0}-R\right)}{3 H_{0}}\left(2 R_{0}^{2}-R_{0} R-R^{2}\right) .
\end{gathered}
$$


Кінематичні модулі паралельної течії (поле швидкостей і тиски деформування)

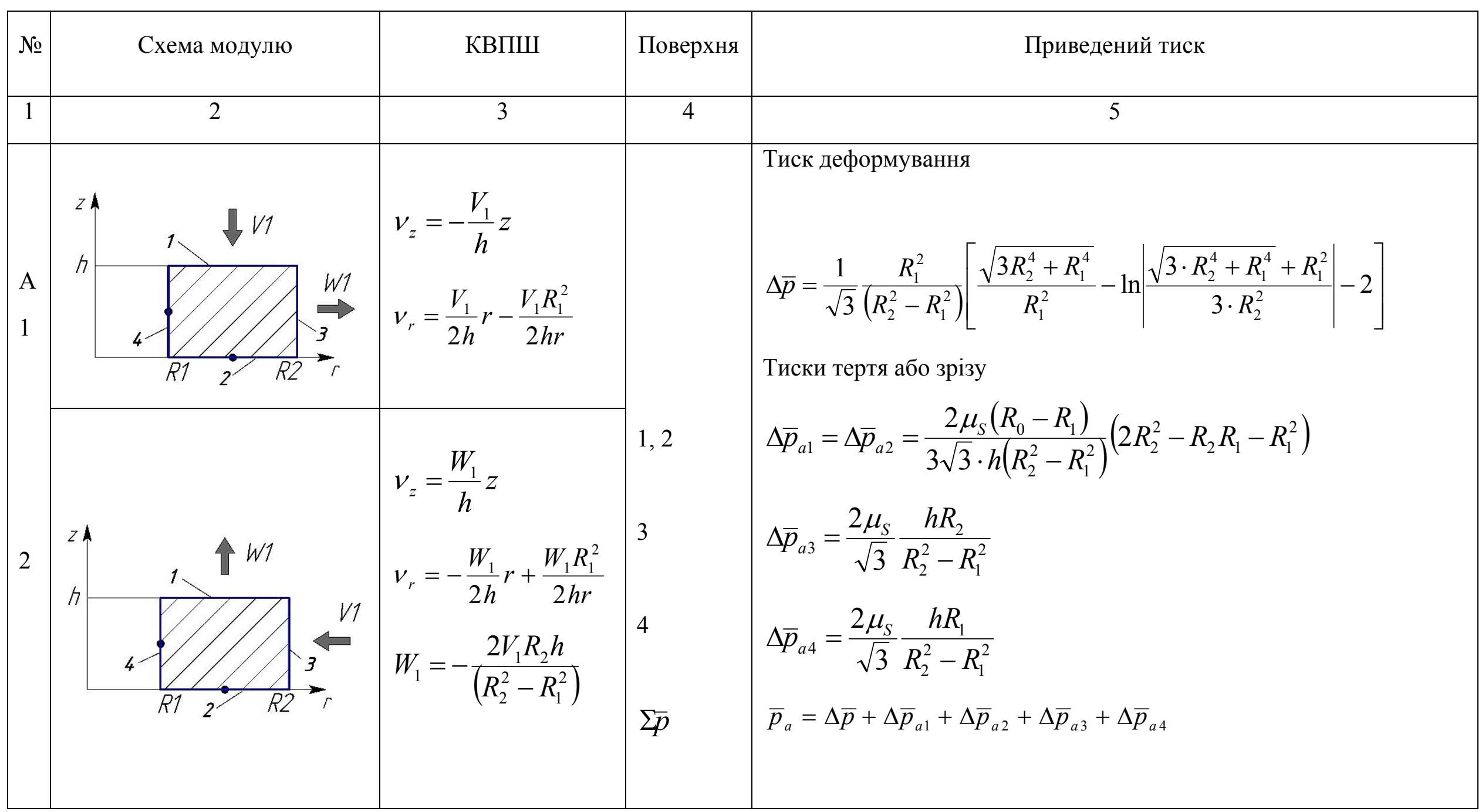


Продовження табл. 1

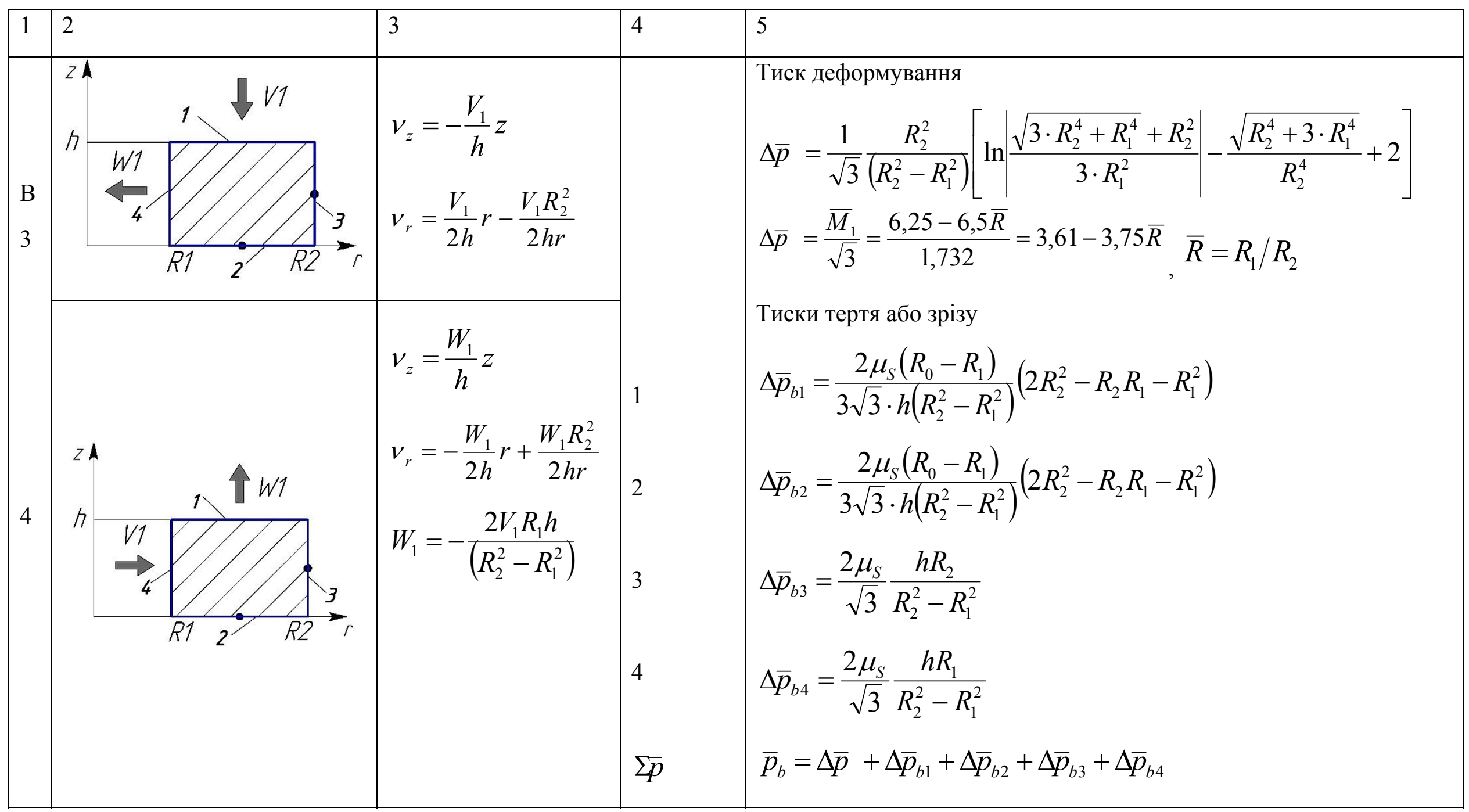


Продовження табл. 1

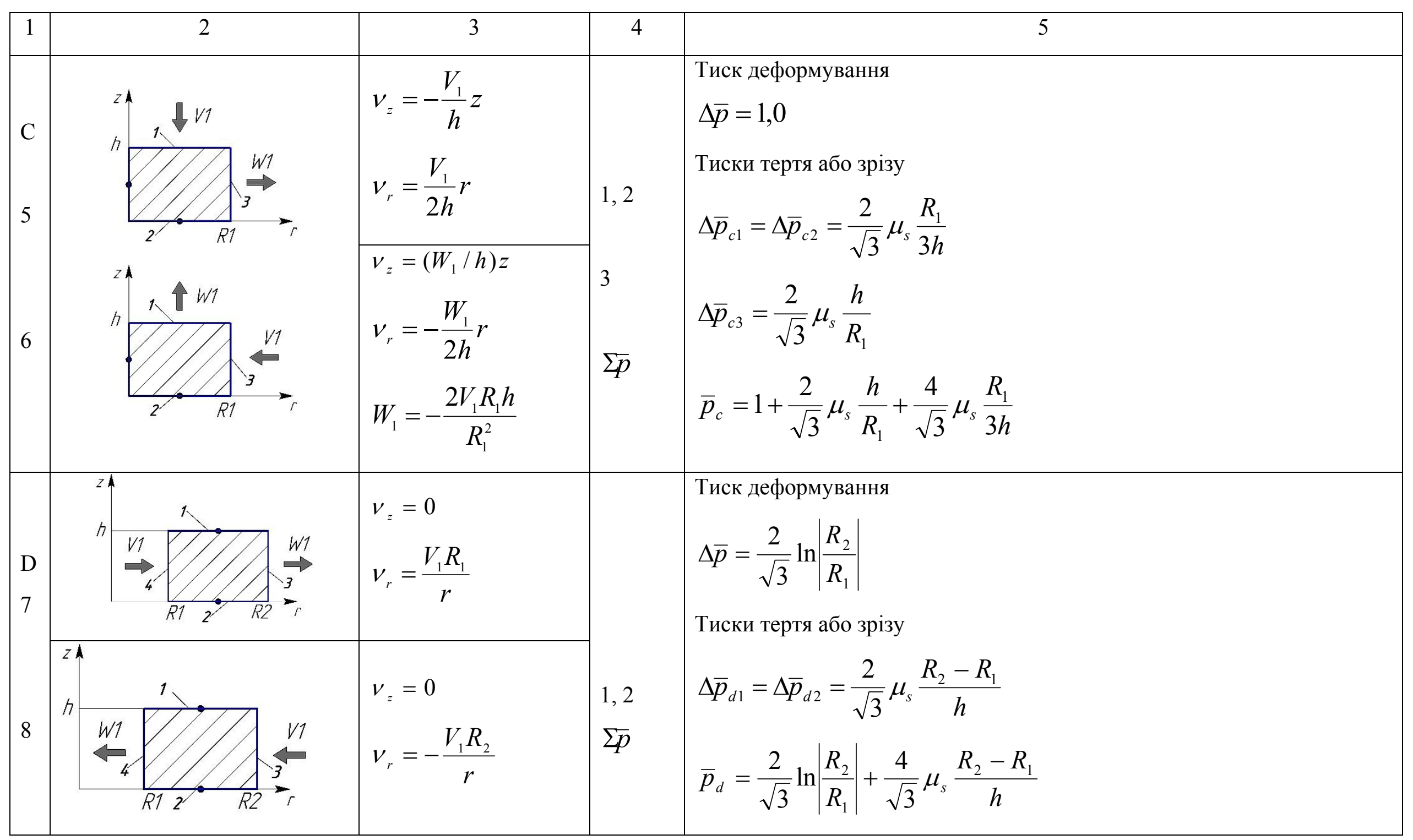


Провівши деякі спрощення для заміни громіздких виразів, отримаємо рівняння в параметричному (безрозмірному) вигляді:

$$
\begin{gathered}
\bar{M}_{1}=2-\sqrt{3 \bar{m}^{4}+1}+\ln \left|\frac{\sqrt{3 \bar{m}^{4}+1}+1}{3 m^{2}}\right| ; \quad \bar{M}_{2}^{*}=\frac{\bar{M}_{1}}{\sqrt{3}}=\frac{6,25-6,5 m}{1,732}=3,61-3,75 m ; \\
\bar{B}_{1}=\frac{(1-m)}{3 \bar{H}_{0}}\left(2-m-m^{2}\right) ; \quad \bar{H}_{0}=H_{0} / R_{0} ; \\
\bar{q}=(3,61-3,75 m)+\frac{\bar{B}_{1}}{\sqrt{3}}+\left(1-m^{2}\right)+\frac{\left(1-m^{2}\right) m}{3 \sqrt{3 \bar{H}_{0}}}+\frac{\bar{H}_{0}}{\sqrt{3 m}}+ \\
+\frac{2}{\sqrt{3}} \mu_{s}\left[\bar{H}_{0}+2 m \bar{l}_{k}\left(\frac{1-m^{2}}{m^{2}}+1+\bar{B}_{1}\right)\right] .
\end{gathered}
$$

Враховуючи залежність (3), для тиску зворотного видавлювання на пуансоні напишемо:

$$
\bar{p}_{1}=\bar{q} \cdot \frac{R_{0}^{2}}{R_{0}^{2}-R^{2}}=\bar{q} \frac{1}{1-m^{2}} .
$$

Для приведеного тиску радіального видавлювання $\bar{p}_{2}$ (в межах зон 5 і 6) використовуємо раніше отриманий вираз [12]. Враховуючи експериментально спостережуване явище відсутності контакту фланця (зони 6), який видавлюється, 3 торцем верхньої напівматриці, в формулу вносимо корективи. В параметричному безрозмірному вигляді формула має вигляд:

$$
\begin{gathered}
\bar{P}_{2}=1+\frac{2}{\sqrt{3}} \ln \bar{R}_{1}+\frac{1}{3 \sqrt{3} \bar{h}}+\frac{\bar{h}}{\sqrt{3}}+\frac{2 \mu_{s}}{\sqrt{3}}\left(\frac{1}{3 \bar{h}}+\frac{\bar{R}_{1}-1}{\bar{h}}+2 \bar{H}_{1}\right) \\
\bar{R}_{1}=R_{1} / R_{0} ., \bar{h}=h / R_{0} ., \bar{H}_{1}=\left(H-H_{0}\right) / R_{0} .
\end{gathered}
$$

При переході від простої схеми зворотного видавлювання відбувається зниження швидкості витікання $W$ i, відповідно, зменшення частини тиску, що витрачається на подолання тертя. Коефіцієнт, що враховує це зниження, можна визначити як:

$$
G=\mu_{s} \frac{\left(l_{k} R\right)}{R_{0}^{2}-R^{2}} .
$$

Нехтуючи силою тертя в межах найжорсткішої зони, яка перемішується зі швидкістю $\lambda V_{0}$, умову рівності потужностей, прикладених по обидва боки до жорсткої зоні 7, напишемо так:

$$
\bar{q}\left(1-\lambda-m^{2}\right)-G \lambda \frac{1}{m^{2}}=\lambda \bar{p}_{2 p}
$$

звідки знаходимо значення коефіцієнта $\lambda$ :

$$
\lambda=\frac{\bar{q}\left(1-m^{2}\right)}{\bar{q}+\bar{p}_{2 p}+G / m^{2}} .
$$

Тоді для сумарного приведеного тиску комбінованого видавлювання можна записати

$$
\bar{p}_{\kappa}=\bar{p}_{1}(1-\lambda)+\bar{p}_{2} \cdot \frac{R_{0}^{2}}{R_{0}^{2}-R^{2}} \lambda-G \frac{R^{2}}{R_{0}^{2}-R^{2}} \lambda
$$


Слід зазначити, що при аналізі отриманої залежності були виконані також спрощення, пов'язані з встановленням оптимальної величини висоти осередку деформації $\bar{H}_{0}=0,2$ і рекомендованої величини паска пуансона $\bar{l}_{k}=0,1$.

Якщо знехтувати впливом $G$, зважаючи на надзвичайну малість $(G \leq 0,1)$, то залежність для приведеного тиску набуває вигляду:

$$
\bar{p}_{k}=\bar{p}_{1}(1-\lambda)+\bar{p}_{2} \cdot \frac{m^{2}}{1-m^{2}} \lambda .
$$

Аналіз залежності параметру $\lambda$ від геометричних параметрів процесу показав, що збільшення відносного радіуса стрижня $\bar{R}$ (рис. 3 , а) призводить до зниження швидкості руху жорсткої зони, а збільшення відносної товщини фланцю $\bar{h}$ (рис. 3 , б) сприяє збільшенню значення $\lambda$, що відповідає більш інтенсивному видавлюванню металу в радіальну порожнину. Збільшення коефіцієнта тертя приводить до зниження значення $\lambda$.

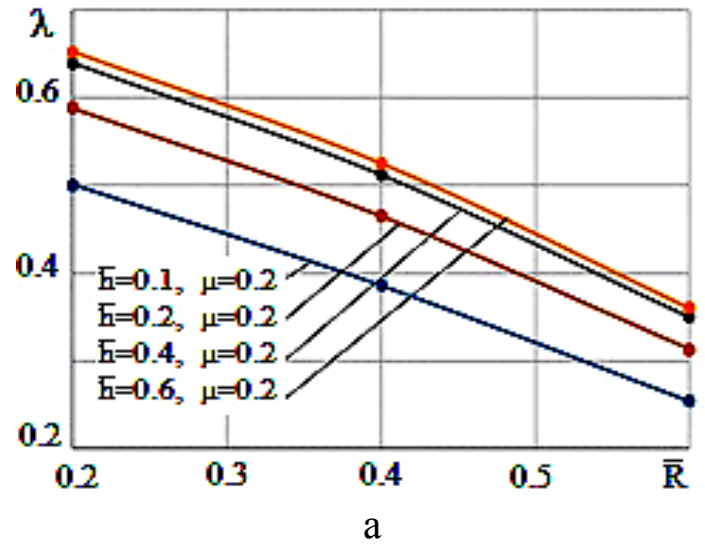

Рис. 3. Графіки залежності параметру $\lambda$ від відносного радіусу стрижня $\bar{R}$ і відносної висоти фланця $\bar{h}$ (б)

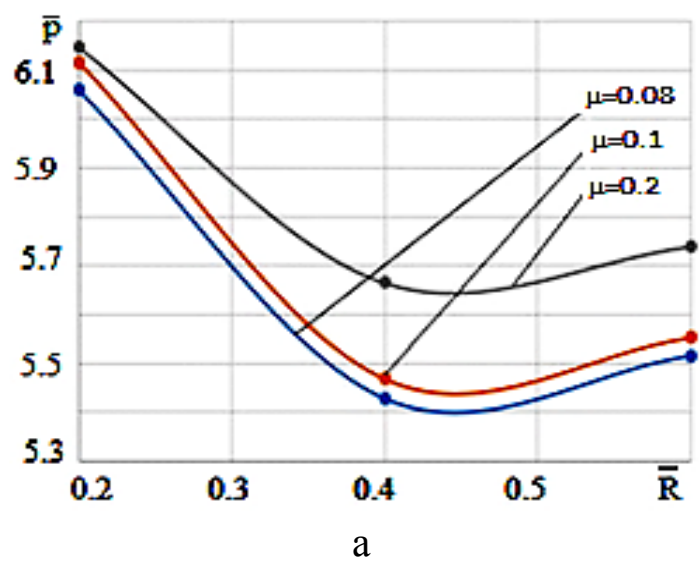

Рис. 4. Графіки залежності приведеного видавлювання від параметрів процесу

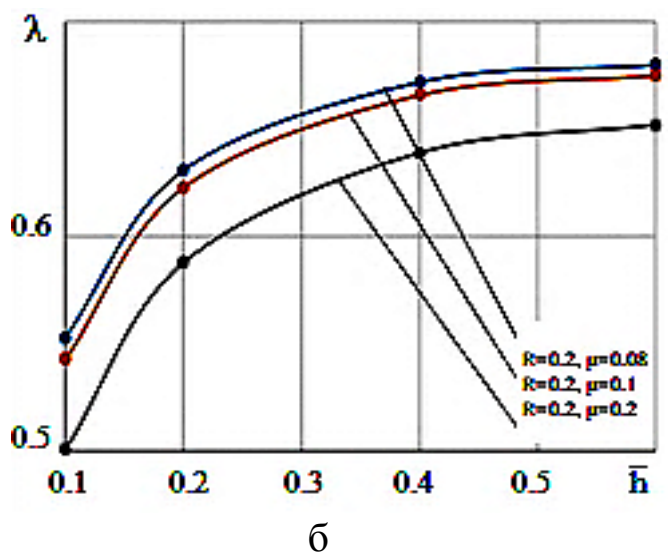

(a)

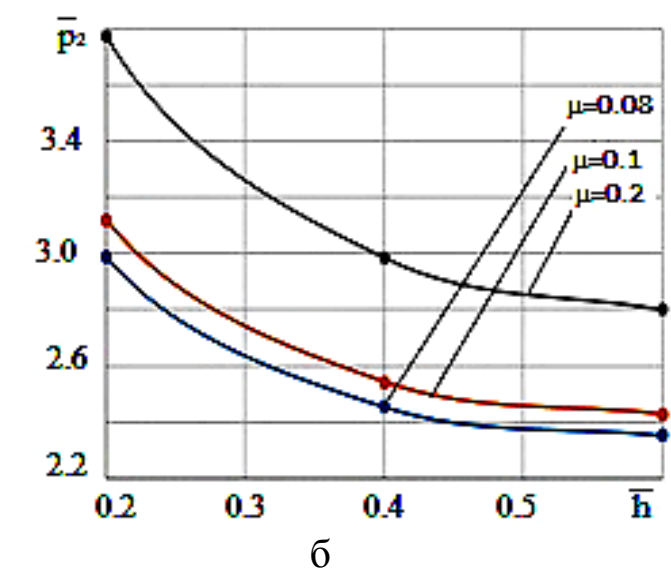

(a) i радіального

Залежності приведеного тиску $\bar{p}$ видавлювання в зворотному і радіальному напрямках показують наявність характерної зони величин відносного діаметру відростку з мінімальним значенням тиску деформування (рис. 4).

Для співставлення виконано аналіз формоутворення при радіально-зворотному видавлюванні стрижневих деталей з фланцем. Для радіально-зворотного видавлювання за аналогією з попередніми розрахунками відносних приростів осьового стрижня та фланця отримано співвідношення: 


$$
\begin{gathered}
\Delta \bar{l}_{1} \uparrow=\left[\left(1-\bar{R}^{2}\right) \cdot(1-\lambda)-\lambda \cdot \bar{R}^{2}\right] \cdot \Delta \bar{H} x ; \\
\Delta \bar{l}_{2} \rightarrow=\sqrt{\frac{\left(1-\bar{R}^{2}\right) \cdot \Delta \bar{H} x-\bar{R}^{2} \cdot \bar{l}_{1} \uparrow}{\bar{h}}+1}-1,
\end{gathered}
$$

де $\Delta \bar{H} x$ - відносний хід пуансона, $\Delta \bar{H} x=S / R_{0}$.

Забезпечення різних умов контактного тертя і можливость використання даного технологічного фактору для керування процесом формоутворення і отримання необхідних кінцевих розмірів деталі $є$ бажаним інструментом. Зменшення тертя при різних співвідношеннях геометричних параметрів процесу відповідає зменшенню відносних приростів стрижня за рахунок збільшення відносних приростів діаметру фланця, що відповідає більш сприятливим умовам для радіального переміщення металу. Відхилення відносних приростів $\Delta \bar{l}_{1} \uparrow$ осьового відростку за різних умов тертя може сягати більше 50 \% від величини (рис. 5, a).

Це відповідає найменшому коефіцієнту тертя, який можна вважати достатньо вагомим технологічним керуючим фактором забезпечення необхідної форми деталі. При цьому спостерігається більш інтенсивне заповнення фланцевої зони деталі (рис. 5, б).

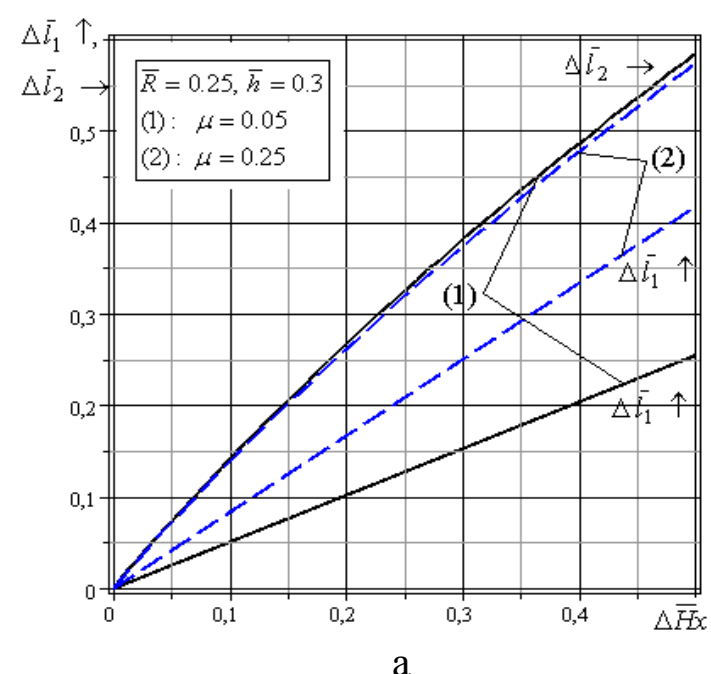

a

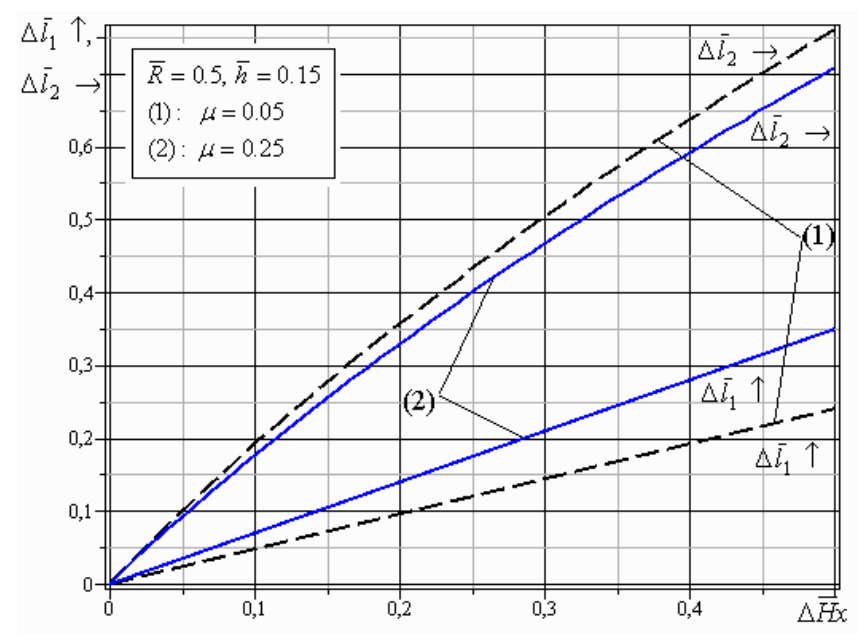

б

Рис. 5. Зміна відносних розмірів стрижня $\Delta \bar{l}_{1} \uparrow$ та фланця $\Delta \bar{l}_{2} \rightarrow$ в залежності від розмірів деталі та умов тертя

Для оцінки закономірності формоутворення штампованих деталей за результатами моделювання були побудовані графіки, які показують характер формування деталі за допомогою встановлення відносного (віднесеного до всього зміщеного об'єму металу) об'єму металу $\bar{V}_{\text {отр }}$, який витрачається на утворення відростка. При цьому змінювалися умови тертя (коефіцієнт тертя $\mu$ ) і геометричні параметри процесу комбінованого видавлювання (рис. 6). Висота заготовки зі сплаву АД31 діаметром 40 мм дорівнювала 50 мм. Видно, що із збільшенням відносної товщини фланця об'єм металу, який витікає в відросток, зменшується. Така тенденція спостерігається до значення $\bar{h}=0.35$ (товщина фланця 5 мм). Після цього збільшується заповнення відростка витіканням металу в зворотному напрямку. Це пояснюється тим, що на першому етапі більш сприятливий напрямок течії спостерігається у фланцеву зону. А на останній стадії при збільшенні діаметру і об'єму відростка підвищується опір деформуванню у фланці і відбувається збільшення обсягу металу, який переміщується в відросток. Збільшення тертя також сприяє більшому переміщенню металу в відросток. 
Порівняння використовуваних методів дослідження проводилося при тих же розмірах заготовки зі сплаву АД31 $(d=20 \mathrm{MM}, h=6 \mathrm{mм}, \mu=0,08)$ і за енергосиловими параметрами процесу (рис. 7).

Встановлено, що значення сил деформування, отримані МСЕ, відрізняються від експериментальних даних в межах 3-7\%; а значення результатів енергетичного методу верхньої оцінки від експерименту відрізняються на 10-15\%.

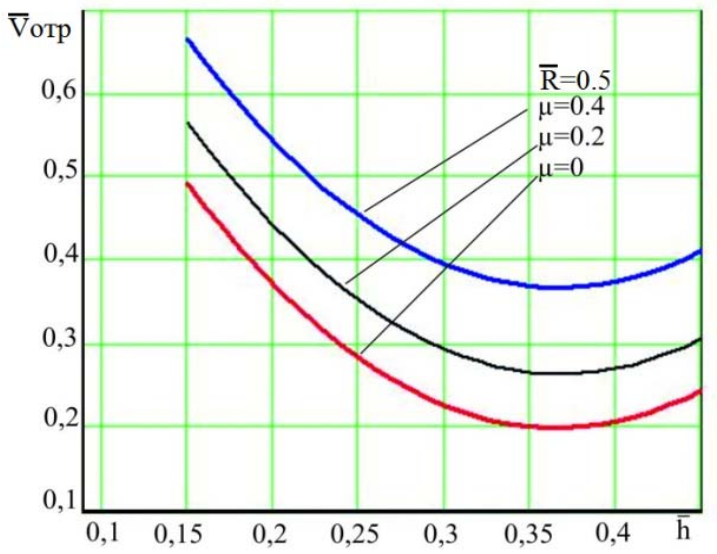

Рис. 6. Залежність об’єму сформованого відростка від відносної товщини фланця

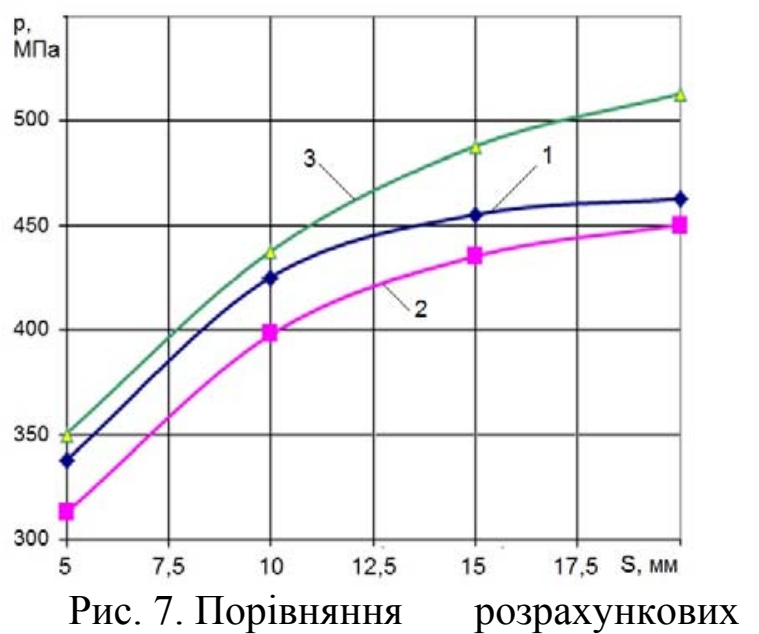

(1 - МСE, 3 - ЕМВО) і експериментальних (2) тисків комбінованого видавлювання

Для оцінки закономірностей формозміни ефективно спостерігати і за наростанням розмірів фланця і відростка при видавлюванні деталей. Картини поетапного наростання контуру деталі, представлені на рис. 8, дають можливість для зіставлення даних за розрахунком формозміни деталі 3 відростком і фланцем двома методами: МСЕ і верхньої оцінки ( $D_{o}=28$ мм, $H_{o}=20$ мм, $d=15$ мм, $h=4$ і 5 мм) [7, 8]. Обидва методи показували, що приріст висоти деталі в порівнянні з вихідною висотою заготовки незначний, а утворення відростка відбувається переважно за рахунок занурення пуансона в заготовку. Цей висновок підтверджується і експериментальними даними.
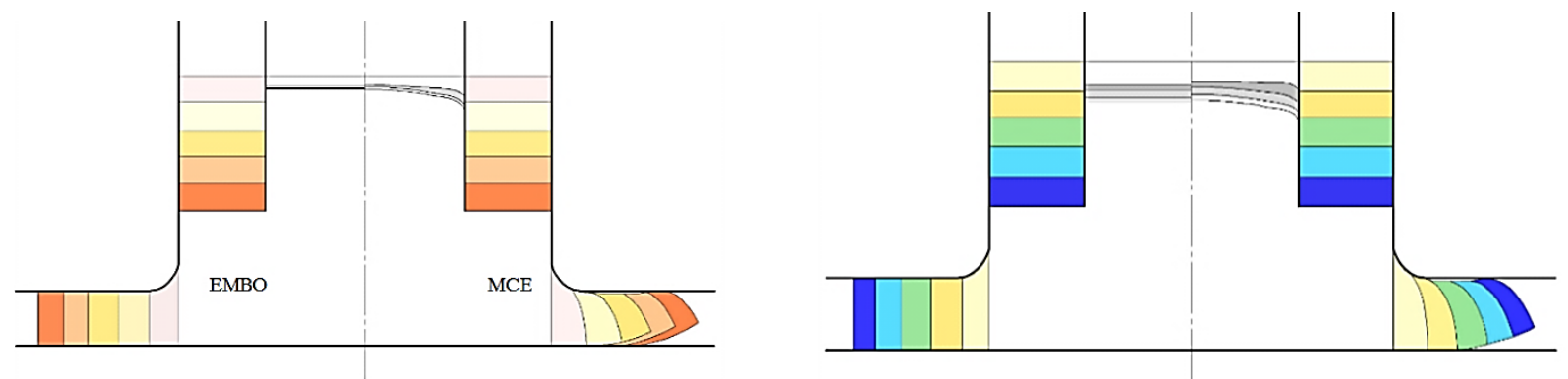

Рис. 8. Зміна геометрії напівфабрикату по ходу процесу, розрахована методом верхньої оцінки (ЕМВО) і методом МСЕ, $h=4$ і 5 мм

Деталі типу «стрижень з фланцем і відростком», отримані радіально-прямим і радіально-зворотним видавлюванням, відрізняються високою точністю розмірів і якістю поверхні (рис. 9, а).

Обмеження пов'язані з точністю діаметральних розмірів фланця і його формою. Це обмеження може бути зняте або виконанням видавлювання в закриту порожнину (рекомендується для деталей з алюмінієвих сплавів), або введенням прийому підсадки фланця в заключній стадії процесу. Види браку також пов'язані з недостатністю пластичності металу в периферійній зоні фланця, який видавлюється, де напружений стан близький до лінійного розтягування (див. рис. 9, б). 
Отримані відомості дозволять дати технологічні рекомендації для отримання якісних деталей типу «стрижень $з$ фланцем» холодним видавлюванням.

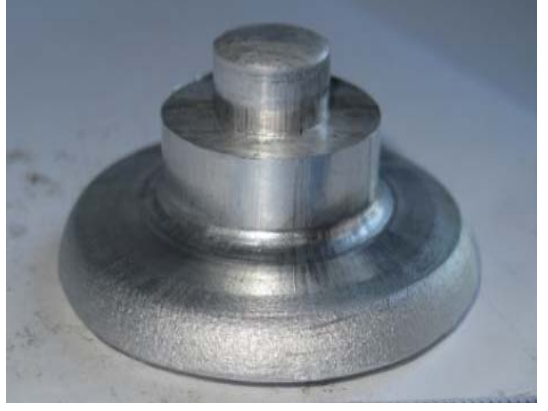

$\mathrm{a}$

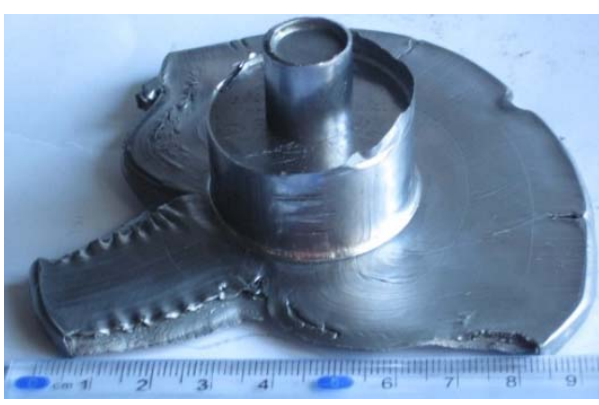

6

Рис. 9. Деталі типу «стрижень 3 фланцем і відростком» (а) і характер руйнування деталей, які отримані комбінованим видавлюванням (б)

\section{ВИСНОВКИ}

Наведено результати моделювання процесу комбінованого радіально-зворотного видавлювання стрижневої деталі з фланцем і відростком енергетичним методом верхньої оцінки і дана оцінка закономірностям формозміни і розвитку напружено-деформованого стану заготовки в процесі комбінованого видавлювання стрижневих деталей. Встановлено, що при комбінованому видавлюванні з витіканням металу в радіальному і зворотному напрямках, осередки інтенсивної пластичної деформації в радіальному і зворотному напрямках розділені і зосереджені в зонах вихідних отворів на перехідних крайках деформуючого інструменту. Ця особливість врахована при аналізі силового режиму шляхом прийняття умови рівноваги проміжної жорсткої зони, що розділяє два осередку деформації.

Встановлено, що кінематичні модулі, обмежені прямолінійними відрізками, мають властивості інверсії, а залежності для потужностей сил тертя і зрізу добре корелюються між собою на протилежних гранях. Модулі підготовлені у вигляді таблиці зі складовими приведеного тиску, які враховують витрати на пластичну деформацію, зрізи та тертя, і можуть бути застосовані для вирішення технологічних задач в ручному і автоматизованому режимах.

Представлені графічні залежності параметрів силового режиму і формозміни заготовки, які дозволяють прогнозувати отримання напівфабрикатів 3 необхідними геометричними параметрами.

Дано зіставлення розрахункових значень параметрів формозміни і силового режиму, отриманих методом кінцевих елементів з енергетичним методом верхньої оцінки і експериментальними даними. Порівняння теоретичних та експериментальних значень тисків деформування і швидкостей течії між собою, а також з результатами, отриманими методом кінцевих елементів і експериментальними даними, показало прийнятність отриманих залежностей для технологічних розрахунків силових параметрів і оцінки формоутворення деталей.

\section{СПИСОК ВИКОРИСТАНОЇ ЛІТЕРАТУРИ}

1. Евстратов В. А. Основы технологии выдавливания и конструирования штампов / В. А. Евстратов. Харьков : Вища школа. Изд-во при Харьк. ун-те, 1987. - 144 c.

2. Aliieva L. Technological possibilities of combined radial - longitudinal extrusion process / Leila Aliieva, Cristina Goncharuk // XVIII International scientific conference New technologies and achievements in metallurgy, material engineering and production engineering. - Series : Monographs. - № 68. - Czestochowa, 2017. - P. $102-107$.

3. Алиева Л. И. Технологические возможности прочессов комбинированного радиально-продольного выдавливания / Л.И. Алиева // Технологические системы. - 2017. - № 1 (78). - C. 31-40. - URL: http://technological-systems.com/images/journal/2017/files/ts78 4.pdf.

4. Алиева Л. И. Прочессы комбинированного деформирования и выдавливания // Обработка материалов давлением: сб. науч. тр. - Краматорск : ДГМА, 2016. - № 1 (42). - С. 100-108.

5. Forming load and deformation energy in combined radial backward extrusion process / H. Y. Lee, B. B. Hwang, S. H. Lee // Proceedings of the Int. Conf. "Metal Forming 2012” 16-19.09.2012, AGH, Krakow. - P. 487-490. 
6. Choi H. J. The forming characteristics of radial-backward extrusion / Choi H. J, Choi J. H., Hwang B. B. // J Mater Process Technol. - 2001. - Nr 113. - P. 141-147.

7. Експериментальне дослідження деформованого стану комбінованого радіально-поздовжнього видавлювання / Л. І. Алієва, С. М. Солодун, Х. В. Гончарук, О. В. Шкіра // Вісник Херсонського національного технічного університету. - Херсон, 2015. - № 4 (55). - С. 82-87.

8. Алиева Л. И. Энергетический анализ процесса комбинированного выдавливания стержневых деталей с фланием / Л. И. Алиева, К. В Гончарук, А. В. Шкира // Обработка материалов давлением : сборник научных трудов. - Краматорск : ДГМА, 2015. - № 2 (41). - С. 35-40.

9. Теория ковки и штамповки / Е. П. Унксов, У. Дюжонсон, В. Л. Колмогоров, В. А. Огородников [и др.] ; под общ. ред. Е. П. Унксова, А. Г. Овчинникова. - М. : Машиностроение, 1992. - 720 с.

10. Алюшин Ю. А. Теоретические основы энергетических методов расчета прочессов обработки металлов давлением : учебное пособие / Ю. А. Алюшин, С. А. Еленев. - Ростов н/Д : РИСХМ, 1987. - 106 с.

11. Степанский Л. Г. Расчеты прочессов обработки металлов давлением / Л. Г. Степанский. - М. : Машиностроение, 1982. - 217 c.

12. Алиева Л. И. Моделирование процесса комбинированного выдавливания фланцев на полых деталях / Л. И. Алиева // Вісник НТУУ «КПІ». Серія Машинобудування. - 2016. - № 1(76). - С. 20-30.

\section{REFERENCES}

1. Evstratov V. A. Osnovy tehnologii vydavlivanija i konstruirovanija shtampov / V. A. Evstratov. - Har'kov : Vishha shkola. Izd-vo pri Har'k. un-te, 1987. - 144 s.

2. Aliieva L. Technological possibilities of combined radial - longitudinal extrusion process / Leila Aliieva, Cristina Goncharuk // XVIII International scientific conference New technologies and achievements in metallurgy, material engineering and production engineering. - Series : Monographs. - № 68. - Czestochowa, 2017. - P. $102-107$.

3. Aliieva L.I. Tehnologicheskie vozmozhnosti processov kombinirovannogo radial'no-prodol'nogo vydavlivanija / L. I. Aliieva // Tehnologicheskie sistemy. - 2017. - № 1 (78). - S. 31-40. - URL: http://technologicalsystems.com/images/journal/2017/files/ts78_4.pdf.

4. Aliieva L. I. Processy kombinirovannogo deformirovanija i vydavlivanija // Obrabotka materialov davleniem : sb. nauch. tr. - Kramatorsk : DGMA, 2016. - № 1 (42). - S. 100-108.

5. Forming load and deformation energy in combined radial backward extrusion process / H. Y. Lee, B. B. Hwang, S. H. Lee // Proceedings of the Int. Conf. "Metal Forming 2012” 16-19.09.2012, AGH, Krakow. - P. 487-490.

6. Choi H. J. The forming characteristics of radial-backward extrusion / Choi H. J, Choi J. H., Hwang B. B. // J Mater Process Technol. - 2001. - Nr 113. - P. 141-147.

7. Eksperymental'ne doslidzhennja deformovanogo stanu kombinovanogo radial'no-pozdovzhn'ogo vydavljuvannja / L. I. Aliieva, Je. M. Solodun, H. V. Goncharuk, O. V. Shkira // Visnyk Hersons'kogo nacional'nogo tehnichnogo universytetu. - Herson, 2015. - № 4 (55). - S. 82-87.

8. Aliieva L. I. Jenergeticheskij analiz processa kombinirovannogo vydavlivanija sterzhnevyh detalej s flancem / L. I. Aliieva, K. V Goncharuk, A. V. Shkira // Obrabotka materialov davleniem : sbornik nauchnyh trudov. Kramatorsk : DGMA, 2015. - № 2 (41). - S. 35-40.

9. Teorija kovki i shtampovki / E. P. Unksov, U. Dzhonson, V. L. Kolmogorov, V. A. Ogorodnikov [i dr.]; pod obshh. red. E. P. Unksova, A. G. Ovchinnikova. - M. : Mashinostroenie, 1992. - 720 s.

10. Aljushin Ju. A. Teoreticheskie osnovy jenergeticheskih metodov rascheta processov obrabotki metallov davleniem : uchebnoe posobie /Ju. A. Aljushin, S. A. Elenev. - Rostov n/D : RISHM, 1987. - 106 s.

11. Stepanskij L. G. Raschety processov obrabotki metallov davleniem / L. G. Stepanskij. $\quad-\quad$ M. : Mashinostroenie, 1982. - 217 s.

12. Aliieva L. I. Modelirovanie processa kombinirovannogo vydavlivanija flancev na polyh detaljah / L. I. Aliieva // Visnik NTUU «KPI». Serija Mashinobuduvannja. - 2016. - № 1(76). - S. 20-30.

Алієва Л. І. - д-р техн. наук, доц. ДДМА; leilialieva2017@gmail.com

Алієв I. C. - д-р техн. наук, зав. кафедри ОМТ дДМА; igramaliev@gmail.com

Грудкіна Н. С. - канд. техн. наук, доц., докторант ДДМА; nata.grudkina@gmail.com

Малій Х. В. - канд. техн. наук, асистент ДДМА. kristina.v.goncharuk@gmail.com

ДДМА - Донбаська державна машинобудівна академія, м. Краматорськ. 